\title{
Long-term field experiments as the basis for practice-oriented humus research - a review
}

Martin Körschens*

Förderverband Humus e. V, Lauchagrund 1, 06246 Goethestadt Bad Lauchstädt, Germany

Abstract

ISSN: 2637-7659

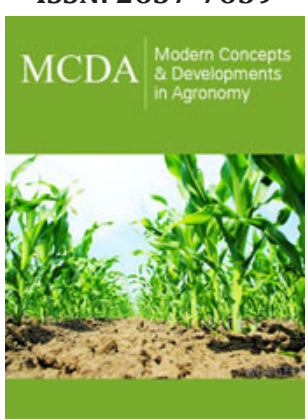

*Corresponding author: Martin Körschens, Förderverband Humus e. V, Lauchagrund 1, 06246 Goethestadt Bad Lauchstädt, Germany

Submission:

Published: 此 September 16, 2021

Volume 9 - Issue 3

How to cite this article: Martin Körschens. Long-term field experiments as the basis for practice-oriented humus research - a review. Mod Concep Dev Agrono. 9(3). MCDA. 000714. 2021. DOI: 10.31031/MCDA.2021.09.000714

Copyright@ Martin Körschens. This article is distributed under the terms of the Creative Commons Attribution 4.0 International License, which permits unrestricted use and redistribution provided that the original author and source are credited.
Organic carbon, Corg, (Soil Organic Matter $=$ Humus $=\mathrm{C}_{\mathrm{org}} \mathrm{x} 1.72$ ) is the prerequisite for soil formation and for maintaining its fertility. All considerations on humus require a differentiation into at least 2 fractions. Humus has always been divided into the fraction's permanent humus (also inert in the sense of not participating in the mineralization processes) and nutrient humus. The results of an evaluation of 79 long-term field experiments worldwide are shown. The initiative of the French government to increase the carbon content of the world's soils by $4 \%$ annually is completely unrealistic.

keywords: Long-term field experiments; Soil Organic Matter; Methodology; Permanent humus; Nutrient humus

\section{Introduction}

The soil is the basis of food production and at the same time human habitat. Organic carbon, $\mathrm{C}_{\text {org }}$ (Soil Organic Matter $=$ Humus $=\mathrm{C}_{\text {org }} \times 1.72$ ) is the prerequisite for soil formation and for maintaining its fertility. It makes the difference between the starting substrate and the soil.

\section{Methodology}

The sufficiently precise determination of $\mathrm{C}_{\text {org }}$ in the soil causes great difficulties with regard to the required precision (agreement of repeated observations) and accuracy (faithful to expectations, undistorted). On the one hand, the reason for this is the relatively high spatial variability. In one field, the range can be up to $0.7 \% \mathrm{C}_{\text {org. }}$ On the other hand, the temporal variability plays a major role [1]. The $\mathrm{C}_{\text {org }}$ content is subject to fluctuations during the growing season as well as between the years, which can amount to more than $0.2 \% \mathrm{C}_{\text {org }}$. Then there is also the analytical error. As methodological studies show, there are ranges here as well that lie between 0.10 and $0.30 \% \mathrm{C}_{\text {org }}$ and obviously correlate with the total content. In many cases, it is also not, or not sufficiently, taken into account that the starting level is decisive for the course of the $\mathrm{C}$ dynamics. The same measures can lead to an increase in the $\mathrm{C}_{\text {org }}$ content at a low starting level, but a reduction in the $\mathrm{C}_{\text {org }}$ content at a high starting level.

\section{Long-term field experiments as the most important experimental basis}

The problem presented makes it clear that long-term field experiments (LTE) are the most important and at the same time an indispensable experimental basis for quantifying the $\mathrm{C}$-dynamics. Their value is based, among other things, on also on the fact that due to the variety of site conditions, the high variability of the soil properties and the required high precision and accuracy, reliable statements can only be made on the basis of long-term investigations taking into account the ceteris paribus principle. For example, annual changes in the $\mathrm{C}_{\text {org }}$ content are well below $0.01 \% \mathrm{C}_{\text {org }}$ at normal practice, the error is ten times that of $>0.1 \%$ $\mathrm{C}_{\text {org }}$, but $0.1 \% \mathrm{C}_{\text {org }}$ is already an order of magnitude that determines the decision. Debreczeni et al. [2] published an overview of 600 Long-term field experiments around the world with an experimental duration of $>10$ years. The oldest LTE, several of them with a duration of 175 years, are in Great Britain [3]. The Static Fertilization Experiment in Bad Lauchstädt, 
created by SCHNEIDEWIND and GRÖBLER in 1902, is one of the most important LTEs today, among others, because:

A. The main series has been unchanged since 1902,

B. With the expansion of the experimental question in 1978

[4], the $\mathrm{C}_{\text {org }}$ content of the soil with a range of 1.6-2.2 could be

introduced as a test factor, which is unique in the world.

C. Additional long-term experiments with high informative value were carried out in 1956, 1983 and 1988.

\section{Result}

All considerations on humus require a differentiation into at least 2 fractions. Humus has always been divided into the fraction's permanent humus (also inert in the sense of not participating in the mineralization processes) and nutrient humus. Schmalfuß [5] already formulated 50 years ago: "Today, a distinction is made between the part that can be degraded by microorganisms, the nutrient humus, and the residue that remains difficult to decompose, the permanent humus." This differentiation is hardly used today for practical purposes still considered and almost exclusively the total humus content assessed, which inevitably leads to irritations and misinterpretations. This applies in particular to the considerations on optimal levels, carbon dynamics, carbon accumulation / enrichment in the soil and climate change. That is also one reason why many $\mathrm{C}$ models do not provide reliable information. Up to 5 different fractions are expected [6], but the actual inert fraction cannot be identified. There is no method of determination that can be used in practice. Permanent humus is defined as the "humus content which, under field conditions, does not fall below any fertilization and cultivation of humus-consuming crops (better fallow land)."

Figure 1 shows the large differences in the content of permanent humus $\mathrm{C}$ depending on the location, whereby the texture of the soil is primarily decisive.



Figure 1: $\mathrm{C}_{\text {org }}$-content in the ploughing layer under bare fallow after many years experimental duration [4].

(Figure 2) shows the relationship between "unfertilized" and "optimal organic-mineral fertilization" using the example of 18 LTE. It is noticeable that only in 3 of 18 LTE the total C content is $>1.5 \%$ and the difference between "unfertilized" and "stable manure + NPK" on the loess black earth in Bad Lauchstädt is comparatively very high.

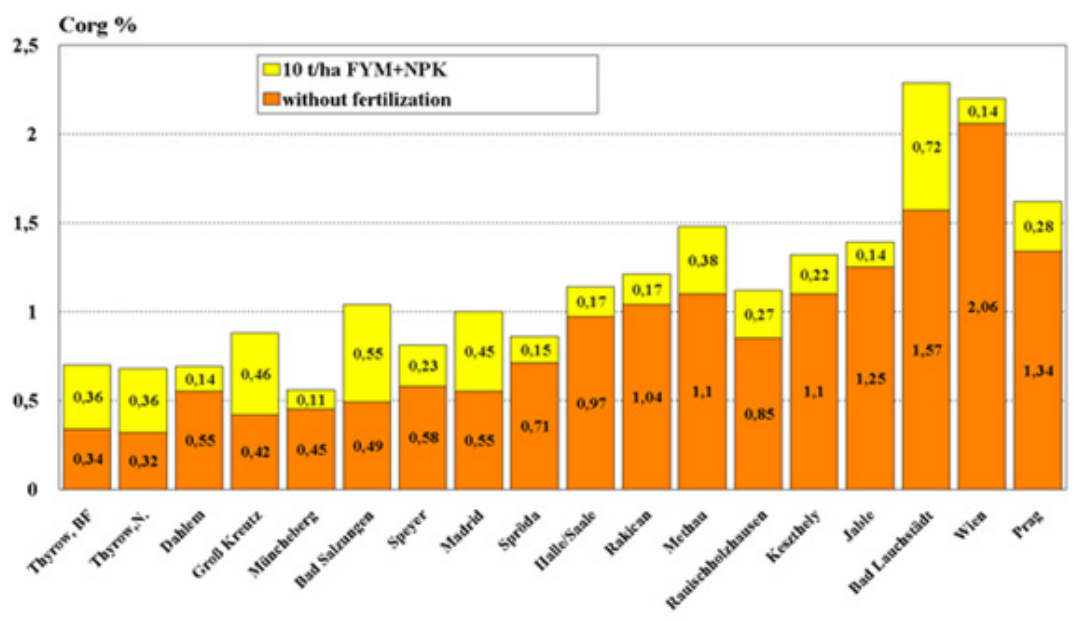

Figure 2: Effect of fertilization on soil organic carbon (SOC) contents in the top soil $(0-30 \mathrm{~cm})$ of 18 European longterm experiments-results from the first decade of the twenty-first century [7] 
There are no benchmarks for carbon and nitrogen, in contrast to almost all other important soil properties. Only the "Humus balance standpoint" of the Association of German Agricultural Investigations and Research Institutes (VDLUFA) gives practice an opportunity to assess the supply status. It is scientifically justified and has been tried and tested in practice.

The results of an evaluation of 79 long-term field experiments worldwide can be summarized as follows:

A. The total humus - $\mathrm{C}$ content in 68 Long-term field experiments is between $0.15 \% \mathrm{C}_{\text {org }}$ and $2.29 \% \mathrm{C}_{\text {org }}$. In 31 of $68 \mathrm{LTE}$, the $\mathrm{C}_{\text {org }}$ content of the optimally organically and minerally fertilized variants is less than $1 \% \mathrm{C}_{\text {org }}(=1.72 \%$ humus $)$.

B. Nutrient humus C averages $0.3 \%$ in 68 LTE and often makes up less than $0.2 \% \mathrm{C}_{\text {org }}$, i. e. H. about $10 \mathrm{t} / \mathrm{ha}$ (with $4500 \mathrm{t}$ / ha soil in the cultivation horizon).

C. The mineral fertilization causes an average of 68LTE to increase the $\mathrm{C}_{\text {org }}$ content by 0.06 to $0.08 \%$ compared to "without".

D. 11t/ha of FYM annually increases the $\mathrm{C}_{\text {org }}$ content in comparison to "unfertilized" by $0.24 \% \mathrm{C}_{\text {org }}$ on average of 42 long-term field experiments.

E. The mineral fertilization secures the nutrition of the people through the high yields and is also the basis of an adequate humus supply.

F. Models are worthless if they are not verified by numerous LTE.

G. The results of 350 comparisons, quantified the yield effect of a combined organic-mineral fertilization in comparison to an optimal, exclusive mineral fertilization with a yield increase of $6 \%[8]$.

H. There are almost functional relationships between $\mathrm{C}_{\text {org }}$ content and soil physical properties [9].

In connection with climate change, humus became the focus of interest at the end of the last century. The initiative of the French government to increase the carbon content of the world's soils by $4 \%$ annually is completely unrealistic. $90 \%$ of the organic primary substance (OPS) added to the soil, based on the initial substance plant biomass, is mineralized again and returned to the atmosphere $[4]$.
According to Haider [10] after just one year, only a little more than $10 \%$ of the $\mathrm{C}$ com- pounds added to the OPS are still present in the soil as "humic substances". Johnston et al, (2017) calculate with only $5 \%$ accumulation. This results in an increase in the $\mathrm{C}_{\text {org }}$ content of the soil by $0.1 \%$ in the cultivation horizon, which corresponds to 4 to $5 \mathrm{t} /$ ha of carbon, with an accumulation of $10 \%$ and $40 \% \mathrm{C}$ in the dry plant matter, a necessary input of 100 to 120 t/ha dry matter. This means that the discussion about "carbon sequestration" is largely unnecessary, the possibilities for this are limited to a few exceptions.

\section{References}

1. Körschens M (2010) Soil organic carbon (C $)$-importance, determination, evaluation. Archives of Agronomy and Soil Science 56(4): 375-392.

2. Debreczeni K, Körschens M (2003) Long-term field experiments of the world. Archives of Agronomy and Soil Science 49(5): 465-483.

3. Poulton PR, Johnston JE, Macdonald AJ, White RP, Powlson DS (2017) Major limitations to achieving “4 per 1000" increases in soil organic carbon stock in temperate regions: Evidence from long-term experiments at Rothamsted Research, United Kingdom. Global Change Biology 24(6): 2563-2584.

4. Körschens M (2021) Long-Term Field Experiments (LTEs)-importance, overview, soil organic matter. In: Mueller L, Sychev VG, Dronin NM, Eulenstein F (Eds.), Exploring and Optimizing Agricultural Landscapes. Innovations in Landscape Research. Springer, pp: 215 -231.

5. Schmalfuss K (1966) Plant nutrition and soil science. S. Hirzel Verlag Leipzig, p. 270.

6. Jenkinson DS, Rayner JH (1977) The turnover of soil organic matter in some of the Rothamsted classical experiments. Soil Science 123(5): 298305 .

7. Körschens M, Kubat J (2015) Soil organic matter- climate changecarbon sequestration? The importance of long-term experiments. In: 60, Anniversary of Long-Term Experiments in the Czech Republic. Prag, pp: 43-50.

8. Körschens M, Albert E, Armbruster M, Barkusky M, Baumecker M, et al. (2013) Effect of mineral and organic fertilization on crop yield, nitrogen uptake, carbon and nitrogen balances, as well as soil organic carbon content and dynamics: results from 20 European long-term field experiments of the twenty-first century. Archives of Agronomy and Soil Science 59(8): 1017-1040.

9. Rühlmann J, Körschens M (2020) Soil particle density as effected by soil texture and soil organic matter: 2. Predicting the effect of the mineral composition of particle-size fractions. Geoderma 375: 114543.

10. Haider K (1996) Biochemie des Bodens, Ferdinand Enke Verlag Stuttgart, Stuttgart, Germany, p. 174. 